\title{
Nurmien väkilannoituksen aiheuttamien ympäristöhaittojen vähentäminen sijoituslannoituksen avulla
}

\author{
Sanna Tyynelä ${ }^{1)}$, Petri Kapuinen ${ }^{1)}$ ja Oiva Niemeläinen ${ }^{2)}$ \\ 1) Maa- ja elintarviketalouden tutkimuskeskus, maatalousteknologian tutkimus, Vakolantie 55, 03400 \\ VIHTI,sanna.tyynela@mtt.fi,petri.kapuinen@mtt.fi \\ 2) Maa- ja elintarviketalouden tutkimuskeskus, kasvintuotannon tutkimus, 31600 JOKIOINEN, \\ oiva.niemelainen@mtt.fi
}

\section{Johdanto}

Väkilannoitteen sijoitusta nurmeen ei ole tutkittu laajasti, kuten lietelannan sijoitusta. Viime aikoina ympäristökysymykset ovat tulleet tärkeiksi, ja maatalouden ympäristötukijärjestelmä kattaa yli $90 \%$ maamme peltopinta-alasta. Nurmiviljely kattaa noin 1/3 maamme peltopinta-alasta. Levitettäessä fosforia monivuotisiin nurmiin useita vuosia peräkkäin nurmen pintaan kertyy runsaasti fosforia vesiliukoisessa muodossa. Lantaa käytettäessä fosforin varastolannoitus ei ole mahdollista, koska ns. nitraattiasetus rajoittaa käyttämästä karjanlannasta tulevaa fosforia merkittävästi yli suojaviljan tarpeen. Sijoitustekniikalla fosfori ei kerry monivuotisten nurmien pinnalle ja sisävesien rehevöitymistä aiheuttava liukoisen fosforin huuhtoutumien vähenee ratkaisevasti.

Sijoitusvantaan vetovastus kasvaa nopeasti sijoitussyvyyden ylittäessä nurmessa $4-5 \mathrm{~cm}$. Matalaan sijoitukseen voidaan käyttää jo nyt kaupallisesti valmistettuja suorakylvökoneita ja tavallisesta kylvölannoittimesta modifioituja koneita. Sijoitustekniikan kehittämisen kannalta on tarpeellista selvittää eri nurmikasvien soveltuvuus sijoitustekniikan käyttöön. Väkilannoitteen lisäksi voidaan sijoittaa rakeistamalla tai muutoin teollisesti prosessoitua karjanlantaa. Vertaamalla matalaan sijoittavia vantaita lietelannan sijoituslaitteen vantaaseen väkilannoitetta levitettäessä säilytetään tuloksien sovellettavuus lietelannan sijoittamiseen. Koska sijoitusvantaiden vaikutukset nurmessa ovat samantyppisiä väkilannoitetta, lietelantaa ja prosessoitua karjanlantaa sijoitettaessa, tutkimus antaa tietoa siitä mille nurmikasveille sijoitustekniikka ylipäätään soveltuu. Karjanlannan levitysmahdollisuuksien lisäämiseksi on lisäksi tarpeellista tarkentaa nurmien lannoitusnormeja nurmikasvilajeittain.

Tutkimuksen tavoitteena on selvittää nurmien väkilannoitukseen soveltuvien koneiden keskinäinen paremmuus käytettäessä kullekin koneelle sopivaa sijoitussyvyyttä sekä sijoituslannoituksen soveltuvuus nurmen lannoitukseen viljeltäessä eri nurmikasveja sekä eri nurmikasveille sopivat lannoitustasot käyttäen mittarina nurmirehusadon määrää, laatua ja menetelmän aiheuttamaa vesistökuormaa.

\section{Aineisto ja menetelmät}

Vihtiin hiesusavelle vuonna 2000 perustetuista viisi nurmikasvilajia (timotei, koiranheinä, nurminata, Englanninraiheinä ja ruokonata) käsittävistä kenttäkokeista korjattiin 3 satoa vuosina 2001 - 2003. Levitystekniikat olivat 3 sijoituslaitteeseen liittyvää sijoitustekniikkaa sekä pintalannoitus. Sijoitustekniikka käytettiin ao. käsittelyissä vain 2. sadolle lannoitettaessa fosforipitoisella (noin $30 \mathrm{~kg} \mathrm{P} / \mathrm{ha} ; 100$ $\mathrm{kg} \mathrm{N} / \mathrm{ha}$ ) lannoitteella. Muuten käytettiin pintalevitystekniikkaa. Levitystekniikkakäsittelyihin levitettiin $100 \mathrm{~kg} \mathrm{~N} / \mathrm{ha} 1$. ja 2. sadolle, typpilannoitusportaat lannoitettiin $0,50,75,100,125 \mathrm{ja} 150 \mathrm{~kg} \mathrm{~N} / \mathrm{ha}$ 1. ja 2. sadolle. 3. sadolle levitettiin kaikkiin ruutuihin $50 \mathrm{~kg} \mathrm{~N} /$ ha pintaan NK-lannoitteena. Kaikki kasvilajit niitettiin samanaikaisesti. Liukoisen fosforin huuhtoutumispotentiaali ja sadon laatutulokset raportoidaan erikseen.

\section{Tulokset ja tulosten tarkastelu}

Nurmiheinälajin ja lannoitusmenetelmän yhdysvaikutus ei ollut tilastollisesti merkitsevä yksittäisen, vuosittaisen tai satovuosien yhteiseen kuiva-ainesatoon, joten mikään nurmiheinälajeista ei soveltunut toista paremmin sijoittamiseen (taulukko 1). Sen sijaan eri nurmiheinälajeilla ja levitysmenetelmillä saatiin toisistaan poikkeavia satoja. Ruokonadan satovuosien yhteinen kuiva-ainesato oli suurin, 18,8 \% suurempi, Englanninraiheinän selvästi pienin, 18,1 \% pienempi kuin keskenään yhtä suuren kuivaainesadon tuottaneiden koiranheinän, nurminadan ja timotein kuiva-ainesato keskimäärin. Tämä järjestys nurmiheinien välille muodostui jo toisena satovuotena. Ruokonadan sadontuotantokyky kehittyi toiselle satovuodelle saakka, ja Englanninraiheinä tuotti suurimman sadon nimenomaisesti ensimmäisen satovuoden ensimmäisessä niitossa. 
Taulukko 1. Lannoitusmenetelmäkokeen kuiva-ainesadot vuosina 2001, 2002 ja 2003 sekä varianssianalyysien tulokset Tukeyn monivertailumenetelmällä.

\begin{tabular}{|c|c|c|c|c|c|c|c|c|c|c|c|c|c|c|}
\hline \multirow{2}{*}{\multicolumn{2}{|c|}{$\begin{array}{c}\text { Lannoitus- } \\
\text { menetelmäkoe }\end{array}$}} & \multicolumn{4}{|c|}{$2001 \mathrm{~kg} \mathrm{ka} / \mathrm{ha}$} & \multicolumn{4}{|c|}{$2002 \mathrm{~kg} \mathrm{ka} / \mathrm{ha}$} & \multicolumn{4}{|c|}{$2003 \mathrm{~kg} \mathrm{ka} / \mathrm{ha}$} & \multirow{2}{*}{$\begin{array}{l}\mathbf{k g ~ k a} / \mathbf{h a} \\
\text { Yhteensä }\end{array}$} \\
\hline & & 1. sato & 2. sato & 3. sato & Yhteensä & 1. sato & 2. sato & 3. sato & Yhteensä & 1. sato & 2. sato & 3. sato & Yhteensä & \\
\hline \multirow{8}{*}{ 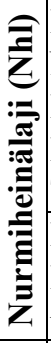 } & Koiranheinä & $3240^{b}$ & $1231^{\mathrm{a}}$ & $2319^{a}$ & $6789^{\mathrm{ab}}$ & $3008^{\mathrm{a}}$ & $2298^{\mathrm{a}}$ & $2954^{c}$ & $8260^{b}$ & $3549^{b}$ & $2347^{b c}$ & $1344^{\mathrm{b}}$ & $7239^{b}$ & $22289^{b}$ \\
\hline & $\mathrm{Nu}$ & $3301^{b}$ & $1092^{\mathrm{ab}}$ & $2200^{\mathrm{a}}$ & $6593^{\mathrm{ab}}$ & $2766^{\mathrm{a}}$ & $1992^{b}$ & $3150^{c}$ & $7908^{b}$ & $3395^{\mathrm{b}}$ & $2072^{\mathrm{bc}}$ & $1078^{\mathrm{bc}}$ & $6545^{\mathrm{b}}$ & $21047^{b}$ \\
\hline & Raih & $4633^{a}$ & $979^{\mathrm{b}}$ & $1595^{\mathrm{b}}$ & $7208^{a}$ & $1015^{\mathrm{b}}$ & $2516^{\mathrm{a}}$ & $2520^{\mathrm{d}}$ & $6051^{\mathrm{c}}$ & $1003^{c}$ & $2534^{\mathrm{b}}$ & $837^{\mathrm{c}}$ & $4374^{\mathrm{c}}$ & $17633^{c}$ \\
\hline & Ruokonata & $2716^{\mathrm{b}}$ & $1199^{\mathrm{ab}}$ & $2563^{\mathrm{a}}$ & $6478^{\mathrm{ab}}$ & $3233^{\mathrm{a}}$ & $2473^{\mathrm{a}}$ & $4398^{a}$ & $10104^{\mathrm{a}}$ & $3617^{b}$ & $3378^{\mathrm{a}}$ & $1981^{\mathrm{a}}$ & $8976^{\mathrm{a}}$ & $25558^{\mathrm{a}}$ \\
\hline & Timotei & $3159^{b}$ & $1016^{\mathrm{ab}}$ & $1717^{\mathrm{b}}$ & $5892^{\mathrm{b}}$ & $2861^{\mathrm{a}}$ & $1846^{\mathrm{b}}$ & $3602^{b}$ & $8309^{\mathrm{b}}$ & $4426^{\mathrm{a}}$ & $1804^{\mathrm{c}}$ & $790^{\mathrm{c}}$ & $7020^{b}$ & $21221^{\mathrm{b}}$ \\
\hline & F-arvo & 17,75 & & & 3,36 & 26,61 & 36,35 & & 42,6 & 74,76 & & & & \\
\hline & DF & 4,12 & 4,12 & 4,12 & 4,12 & 4,12 & 4,12 & 4,12 & 4,12 & 4,12 & 4,12 & 4,12 & 4,12 & 4,12 \\
\hline & p-arvo & $<, 0001 * * *$ & $0,0224^{*}$ & $<, 0001 * * *$ & $0,0459 *$ & $<, 0001 * * *$ & $<, 0001 * * *$ & $<, 0001 * * *$ & $<, 0001 * * *$ & $<, 0001 * * *$ & $<, 0001 * * *$ & $<, 0001 * * *$ & $<, 0001 * * *$ & $<, 0001 * * *$ \\
\hline \multirow{7}{*}{ 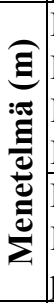 } & Pintalannoitus & 3457 & $1447^{\mathrm{a}}$ & & $6911^{\mathrm{a}}$ & 2558 & $2565^{\mathrm{a}}$ & 2 & $8455^{\mathrm{a}}$ & 3161 & $2938^{\mathrm{a}}$ & $1237^{\mathrm{a}}$ & $7336^{\mathrm{a}}$ & $22701^{\mathrm{a}}$ \\
\hline & Kiekkov & & $1021^{\mathrm{b}}$ & $2100^{\mathrm{ab}}$ & $6437^{b}$ & 34 & $2118^{b c}$ & & $8007^{\mathrm{b}}$ & 3246 & $2231^{b c}$ & $1192^{\mathrm{ab}}$ & $6669^{b c}$ & $21113^{b}$ \\
\hline & Lautasvannas & 3467 & $968^{b}$ & $2065^{\mathrm{ab}}$ & $6500^{\mathrm{b}}$ & 2622 & $2187^{b}$ & 3 & $8157^{\mathrm{ab}}$ & 3237 & $2369^{b}$ & $1250^{\mathrm{a}}$ & $6856^{\mathrm{b}}$ & \\
\hline & Lietesijoitin & 34 & $977^{\mathrm{b}}$ & 21 & $6521^{\mathrm{ab}}$ & 2542 & $2031^{\mathrm{c}}$ & & $7887^{\mathrm{b}}$ & 3147 & $2171^{\mathrm{c}}$ & $1145^{\mathrm{b}}$ & $6464^{c}$ & $71^{\mathrm{b}}$ \\
\hline & F-arvo & 0,75 & 70,48 & & 4 & 7 & 48 & & 7 & 0 & 74 & & 20 & 15,83 \\
\hline & DF & 3,45 & 3,45 & & 3,45 & 3,45 & 3,45 & & 3,45 & 3,45 & 3,45 & 3, & 3,45 & 3,45 \\
\hline & p-arvo & 0,5298 & $<, 0001 * * *$ & $0,0437^{*}$ & 0,01 & 0,7067 & $<, 0001 * * *$ & & $0,0003 * * *$ & 0,4 & $<, 0001 * * *$ & $0,0159 *$ & $<, 0001 * * *$ & $<, 0001 * * *$ \\
\hline \multirow{3}{*}{$\begin{array}{c}\mathbf{\Xi} \\
* \\
\mathbf{z} \\
\mathbf{Z}\end{array}$} & F-arvo & 0,64 & 0,58 & & 0,72 & 0,89 & 0,93 & 1,73 & 1,31 & 0,41 & 1,87 & 0,62 & 0,68 & 0,89 \\
\hline & DF & 12,45 & 12,45 & 12,45 & 12,45 & 12,45 & 12,45 & 12,45 & 12,45 & 12,45 & 12,45 & 12,45 & 12,45 & 12,45 \\
\hline & p-arvo & 0,8000 & 0,8434 & 0,2951 & 0,7245 & 0,5631 & 0,5233 & $0,0919 \mathrm{o}$ & 0,2474 & 0,9524 & 0,06460 & 0,8130 & 0,7629 & 0,5635 \\
\hline
\end{tabular}

- ${ }^{\text {a,b,c,d }}$ Saman sarakekokonaisuuden käsittelykeskiarvot, joilla ei ole yhteistä kirjainta, eroavat tilastollisesti merkitsevästi 5 \%:n riskitasolla.

Taulukko 2. Lannoitustasokokeen vuosien 2001,2002 ja 2003 varianssianalyysien tulokset Tukeyn monivertailumenetelmällä.

\begin{tabular}{|c|c|c|c|c|c|c|c|c|c|c|c|c|c|}
\hline \multirow{2}{*}{ Lannoitustasokoe } & \multicolumn{4}{|c|}{$2001 \mathrm{~kg} \mathrm{ka} / \mathrm{ha}$} & \multicolumn{4}{|c|}{$2002 \mathrm{~kg} \mathrm{ka} / \mathrm{ha}$} & \multicolumn{4}{|c|}{$2003 \mathrm{~kg} \mathrm{ka} / \mathrm{ha}$} & \multirow{2}{*}{$\begin{array}{l}\mathbf{k g ~ k a} / \mathbf{h a} \\
\text { Yhteensä }\end{array}$} \\
\hline & 1. sato & 2. sato & 3. sato & Isä & 1. sato & 2. sato & 3. sato & nsä & 1. sato & 2. sato & 3. sato & $\mathrm{Yh}$ & \\
\hline \begin{tabular}{l|l} 
& F-arvo
\end{tabular} & 18,11 & 7,41 & 23,78 & 7,59 & 13,18 & 23,15 & 22,93 & & 112,89 & 45,51 & & & 10,92 \\
\hline $\bar{z} \mathrm{DF}$ & 4,12 & 4,12 & 4,12 & 4,12 & 4,12 & 4,12 & 4,12 & 4,12 & 4,12 & 4,12 & 4,12 & 4,12 & 4,12 \\
\hline p-arvo & $<, 0001 * * *$ & $0,0030 * *$ & $<, 0001 * * *$ & $0,0027 * *$ & $0,0002 * * *$ & $<, 0001 * * *$ & $<, 0001 * * *$ & $0,0001 * * *$ & $<, 0001 * * *$ & $<, 0001 * * *$ & $<, 0001 * * *$ & $<, 0001 * * *$ & $0,0006 * * *$ \\
\hline \multirow{3}{*}{ 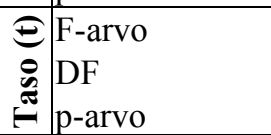 } & & & & & & & & & & & & & \\
\hline & 5,75 & 5,75 & 5,75 & 5,75 & 5,75 & 5,75 & 5,75 & 5,75 & 5,75 & 5,75 & 5,75 & 5,75 & 5 , \\
\hline & $<, 0001 * * *$ & $<, 0001 * * *$ & $<, 0001 * * *$ & $<, 0001 * * *$ & $<, 0001 * * *$ & $<, 0001 * * *$ & $<, 0001 * * *$ & $<, 0001 * * *$ & $<, 0001 * * *$ & $<, 0001 * * *$ & $<, 0001 * * *$ & $<, 0001 * * *$ & $<, 0001 * *$ \\
\hline \multirow{3}{*}{ 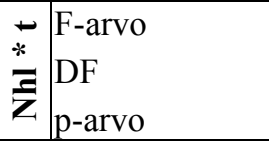 } & 1,55 & 3,04 & 3,59 & 2,68 & 3,23 & 6,66 & 3,52 & 2,74 & 19,61 & 7,03 & 6,23 & 8,32 & 6,11 \\
\hline & 20,75 & 20,75 & 20,75 & 20,75 & 20,75 & 20,75 & 20,75 & 20,75 & 20,75 & 20,75 & 20,75 & 20,75 & 20,75 \\
\hline & $0,0889 \mathrm{o}$ & $0,0003 * * *$ & $<, 0001 * * *$ & $0,0011 * *$ & $<, 0001 * * *$ & $<, 0001 * * *$ & $<, 0001 * * *$ & $0,0009 * * *$ & $<, 0001 * * *$ & $<, 0001 * * *$ & $<, 0001 * * *$ & $<, 0001 * * *$ & $<, 0001 * * *$ \\
\hline
\end{tabular}


Taulukko 3. Lannoitustasokokeen kuiva-ainesadot vuosina 2001, 2002 ja 2003 sekä varianssianalyysien tulokset Tukeyn monivertailumenetelmällä.

\begin{tabular}{|c|c|c|c|c|c|c|c|c|c|c|c|c|c|c|}
\hline \multirow{2}{*}{$\begin{array}{l}\text { Nurmi- } \\
\text { heinälaii }\end{array}$} & \multirow{2}{*}{$\begin{array}{c}\text { Taso } \\
\text { kg N/ha }\end{array}$} & \multicolumn{4}{|c|}{$2001 \mathrm{~kg} \mathrm{ka} / \mathrm{ha}$} & \multicolumn{4}{|c|}{$2002 \mathrm{~kg} \mathrm{ka} / \mathrm{ha}$} & \multicolumn{4}{|c|}{$2003 \mathrm{~kg} \mathrm{ka} / \mathrm{ha}$} & \multirow{2}{*}{$\begin{array}{l}\mathbf{k g} \mathbf{k a} / \mathbf{h a} \\
\text { Yhteensä }\end{array}$} \\
\hline & & 1. sato & 2. sato & 3. sato & |Yhteensä & 1. sato & 2. sato & 3. sato & Yhteensä & 1. sato & 2. sato & 3. sato & Yhteensä & \\
\hline \multirow{6}{*}{$\begin{array}{c}\text { Koiran- } \\
\text { heinä }\end{array}$} & 0 & $1493^{\mathrm{c}}$ & $248^{\mathrm{c}}$ & $1197^{\mathrm{e}}$ & $2938^{\mathrm{d}}$ & $1206^{\mathrm{d}}$ & $245^{\mathrm{d}}$ & $2165^{\mathrm{c}}$ & $3615^{\mathrm{d}}$ & $483^{\mathrm{d}}$ & $261^{\mathrm{c}}$ & 1235 & $1979^{\mathrm{d}}$ & $8533^{\mathrm{d}}$ \\
\hline & 50 & $3485^{\mathrm{b}}$ & $1722^{b}$ & $1670^{\mathrm{d}}$ & $6877^{\mathrm{c}}$ & $2862^{c}$ & $2012^{\mathrm{c}}$ & $3010^{\mathrm{b}}$ & $7883^{c}$ & $2146^{\mathrm{c}}$ & $2198^{b}$ & 1265 & $5608^{c}$ & $20369^{c}$ \\
\hline & 75 & $3855^{\mathrm{ab}}$ & $2135^{\mathrm{ab}}$ & $1978^{\text {cd }}$ & $7968^{\mathrm{bc}}$ & $3094^{\mathrm{bc}}$ & $2722^{\mathrm{b}}$ & $3289^{\mathrm{ab}}$ & $9104^{\mathrm{b}}$ & $3321^{\mathrm{b}}$ & $2796^{\mathrm{ab}}$ & 1293 & $7410^{\mathrm{b}}$ & $24482^{\mathrm{b}}$ \\
\hline & 100 & $4298^{\mathrm{ab}}$ & $2347^{\mathrm{a}}$ & $2168^{\mathrm{bc}}$ & $8813^{\mathrm{ab}}$ & $3577^{\mathrm{ab}}$ & $3134^{\mathrm{ab}}$ & $3496^{\mathrm{ab}}$ & $10207^{\mathrm{ab}}$ & $3954^{\mathrm{ab}}$ & $3236^{\mathrm{a}}$ & 1439 & $8629^{a}$ & $27649^{a}$ \\
\hline & 125 & $4254^{\mathrm{ab}}$ & $2466^{\mathrm{a}}$ & $2388^{\mathrm{ab}}$ & $9107^{\mathrm{ab}}$ & $3878^{\mathrm{a}}$ & $3280^{\mathrm{a}}$ & $3639^{\mathrm{a}}$ & $10796^{\mathrm{a}}$ & $4303^{a}$ & $3210^{\mathrm{a}}$ & 1270 & $8783^{\mathrm{a}}$ & $28687^{\mathrm{a}}$ \\
\hline & 150 & $4703^{\mathrm{a}}$ & $2501^{\mathrm{a}}$ & $2779^{\mathrm{a}}$ & $9983^{\mathrm{a}}$ & $3730^{\mathrm{ab}}$ & $3250^{\mathrm{a}}$ & $3723^{a}$ & $10702^{\mathrm{a}}$ & $4575^{\mathrm{a}}$ & $2922^{\mathrm{a}}$ & 1428 & $8925^{\mathrm{a}}$ & $29610^{\mathrm{a}}$ \\
\hline \multirow{6}{*}{ Nurminata } & 0 & $2044^{c}$ & $277^{\mathrm{d}}$ & $1303^{d}$ & $3623^{\mathrm{d}}$ & $1365^{\mathrm{b}}$ & $217^{\mathrm{d}}$ & $1864^{\mathrm{c}}$ & $3445^{c}$ & $542^{\mathrm{d}}$ & $185^{\mathrm{c}}$ & $623^{\mathrm{b}}$ & $1350^{\mathrm{d}}$ & $8418^{\mathrm{d}}$ \\
\hline & 50 & $3888^{\mathrm{b}}$ & $1433^{\mathrm{c}}$ & $2069^{c}$ & $7390^{c}$ & $2504^{\mathrm{a}}$ & $1355^{\mathrm{c}}$ & $2533^{\mathrm{b}}$ & $6392^{\mathrm{b}}$ & $1722^{c}$ & $1722^{\mathrm{b}}$ & $1112^{\mathrm{a}}$ & $4557^{\mathrm{c}}$ & $18339^{\mathrm{c}}$ \\
\hline & 75 & $4272^{\mathrm{ab}}$ & $1862^{\mathrm{b}}$ & $2321^{b c}$ & $8455^{\mathrm{bc}}$ & $2800^{\mathrm{a}}$ & $2065^{\mathrm{b}}$ & $3051^{\mathrm{ab}}$ & $7916^{\mathrm{a}}$ & $2623^{\mathrm{b}}$ & $2263^{\mathrm{ab}}$ & $1273^{\mathrm{a}}$ & $6158^{\mathrm{b}}$ & $22529^{b}$ \\
\hline & 100 & $4549^{\mathrm{ab}}$ & $2068^{\mathrm{ab}}$ & $2567^{\mathrm{ab}}$ & $9184^{\mathrm{ab}}$ & $2911^{\mathrm{a}}$ & $2363^{a b}$ & $3267^{\mathrm{a}}$ & $8542^{\mathrm{a}}$ & $3109^{a b}$ & $2491^{\mathrm{a}}$ & $1283^{\mathrm{a}}$ & $6883^{a b}$ & $24609^{\mathrm{ab}}$ \\
\hline & 125 & $4826^{\mathrm{ab}}$ & $2143^{\mathrm{ab}}$ & $2639^{a b}$ & $9607^{\mathrm{ab}}$ & $2869^{a}$ & $2662^{\mathrm{a}}$ & $3415^{\mathrm{a}}$ & $8946^{\mathrm{a}}$ & $3382^{\mathrm{a}}$ & $2473^{\mathrm{a}}$ & $1293^{\mathrm{a}}$ & $7147^{\mathrm{ab}}$ & $25700^{\mathrm{a}}$ \\
\hline & 150 & $5097^{\mathrm{a}}$ & $2308^{\mathrm{a}}$ & $2768^{\mathrm{a}}$ & $10173^{\mathrm{a}}$ & $2714^{\mathrm{a}}$ & $2672^{\mathrm{a}}$ & $3630^{a}$ & $9015^{\mathrm{a}}$ & $3504^{\mathrm{a}}$ & $2715^{\mathrm{a}}$ & $1205^{\mathrm{a}}$ & $7424^{\mathrm{a}}$ & $26612^{a}$ \\
\hline \multirow{6}{*}{$\begin{array}{c}\text { Englannin- } \\
\text { raiheinä }\end{array}$} & 0 & $2756^{\mathrm{c}}$ & $181^{\mathrm{c}}$ & $791^{d}$ & $3728^{\mathrm{d}}$ & $726^{b}$ & $368^{d}$ & $1206^{\mathrm{d}}$ & $2299^{d}$ & 77 & $170^{\mathrm{d}}$ & 587 & $833^{d}$ & $6860^{\mathrm{d}}$ \\
\hline & 50 & $5722^{b}$ & $1308^{b}$ & $1616^{\mathrm{c}}$ & $8645^{\mathrm{c}}$ & $1726^{\mathrm{a}}$ & $2148^{c}$ & $2142^{c}$ & $6015^{\mathrm{c}}$ & 530 & $2105^{\mathrm{c}}$ & 897 & $3532^{c}$ & $18192^{\mathrm{c}}$ \\
\hline & 75 & $6037^{\mathrm{ab}}$ & $1738^{a}$ & $1707^{b c}$ & $9483^{\mathrm{bc}}$ & $1877^{\mathrm{a}}$ & $2893^{\mathrm{b}}$ & $2515^{b c}$ & $7285^{b}$ & 679 & $3088^{\mathrm{b}}$ & 909 & $4676^{\mathrm{b}}$ & $21444^{b}$ \\
\hline & 100 & $6431^{\mathrm{ab}}$ & $2065^{\mathrm{a}}$ & $1834^{\mathrm{bc}}$ & $10329^{\mathrm{ab}}$ & $1990^{\mathrm{a}}$ & $3109^{\mathrm{ab}}$ & $2827^{\mathrm{b}}$ & $7925^{\mathrm{ab}}$ & 808 & $4282^{\mathrm{a}}$ & 768 & $5858^{\mathrm{a}}$ & $24113^{a}$ \\
\hline & 125 & $6562^{\mathrm{ab}}$ & $2060^{\mathrm{a}}$ & $2043^{\mathrm{ab}}$ & $10665^{\mathrm{ab}}$ & $1821^{\mathrm{a}}$ & $3428^{\mathrm{a}}$ & $2945^{\mathrm{ab}}$ & $8194^{\mathrm{ab}}$ & 578 & $4137^{\mathrm{a}}$ & 791 & $5506^{\mathrm{ab}}$ & $24365^{a}$ \\
\hline & 150 & $6859^{\mathrm{a}}$ & $2110^{\mathrm{a}}$ & $2277^{\mathrm{a}}$ & $11246^{\mathrm{a}}$ & $1945^{\mathrm{a}}$ & $3470^{\mathrm{a}}$ & $3489^{\mathrm{a}}$ & $8904^{\mathrm{a}}$ & 372 & $3882^{\mathrm{a}}$ & 641 & $4894^{\mathrm{ab}}$ & $25045^{\mathrm{a}}$ \\
\hline \multirow{6}{*}{ Ruokonata } & 0 & $1919^{b}$ & $436^{c}$ & $1453^{d}$ & $3808^{c}$ & $1719^{b}$ & $415^{d}$ & $2734^{c}$ & $4868^{\mathrm{c}}$ & $859^{d}$ & $591^{\mathrm{c}}$ & $1256^{\mathrm{b}}$ & $2707^{d}$ & $11382^{d}$ \\
\hline & 50 & $3558^{\mathrm{a}}$ & $1714^{\mathrm{b}}$ & $2387^{\mathrm{c}}$ & $7660^{\mathrm{b}}$ & $2838^{\mathrm{a}}$ & $2112^{\mathrm{c}}$ & $4079^{b}$ & $9028^{\mathrm{b}}$ & $2432^{\mathrm{c}}$ & $3000^{\mathrm{b}}$ & $2082^{\mathrm{a}}$ & $7514^{\mathrm{c}}$ & $24202^{c}$ \\
\hline & 75 & $3678^{\mathrm{a}}$ & $2046^{\mathrm{ab}}$ & $2624^{b c}$ & $8347^{\mathrm{b}}$ & $3229^{a}$ & $2591^{\mathrm{b}}$ & $4780^{\mathrm{a}}$ & $10620^{\mathrm{a}}$ & $2942^{\text {bc }}$ & $3833^{\mathrm{a}}$ & $2238^{\mathrm{a}}$ & $9013^{\mathrm{b}}$ & $27980^{\mathrm{b}}$ \\
\hline & 100 & $4077^{\mathrm{a}}$ & $2139^{\mathrm{a}}$ & $2673^{\mathrm{abc}}$ & $8889^{\mathrm{ab}}$ & $3376^{\mathrm{a}}$ & $3074^{\mathrm{a}}$ & $4899^{a}$ & $11348^{a}$ & $3507^{\mathrm{ab}}$ & $3960^{\mathrm{a}}$ & $2119^{a}$ & $9586^{\mathrm{ab}}$ & $29824^{\mathrm{ab}}$ \\
\hline & 125 & $4418^{a}$ & $2381^{\mathrm{a}}$ & $2917^{\mathrm{ab}}$ & $9715^{\mathrm{a}}$ & $3369^{a}$ & $3270^{\mathrm{a}}$ & $5107^{\mathrm{a}}$ & $11746^{\mathrm{a}}$ & $3821^{\mathrm{a}}$ & $4413^{a}$ & $2246^{\mathrm{a}}$ & $10480^{\mathrm{a}}$ & $31941^{\mathrm{a}}$ \\
\hline & 150 & $4341^{\mathrm{a}}$ & $2258^{\mathrm{a}}$ & $3055^{\mathrm{a}}$ & $9654^{\mathrm{a}}$ & $3497^{\mathrm{a}}$ & $2955^{\mathrm{ab}}$ & $5187^{\mathrm{a}}$ & $11640^{\mathrm{a}}$ & $3823^{a}$ & $4200^{\mathrm{a}}$ & $2097^{\mathrm{a}}$ & $10119^{\mathrm{a}}$ & $31414^{\mathrm{a}}$ \\
\hline \multirow{6}{*}{ Timotei } & 0 & $2006^{b}$ & $186^{\mathrm{c}}$ & $1016^{\mathrm{c}}$ & $3208^{\mathrm{c}}$ & $1601^{b}$ & $193^{\mathrm{c}}$ & $2740^{\mathrm{c}}$ & $4535^{\mathrm{c}}$ & $1077^{\mathrm{b}}$ & $109^{c}$ & 792 & $1978^{\mathrm{c}}$ & $9721^{\mathrm{c}}$ \\
\hline & 50 & $4097^{\mathrm{a}}$ & $1223^{\mathrm{b}}$ & $1238^{\mathrm{bc}}$ & $6559^{\mathrm{b}}$ & $2994^{\mathrm{a}}$ & $1743^{\mathrm{b}}$ & $3413^{b}$ & $8151^{\mathrm{b}}$ & $3771^{\mathrm{a}}$ & $1405^{\mathrm{b}}$ & 832 & $6008^{b}$ & $20718^{b}$ \\
\hline & 75 & $4387^{\mathrm{a}}$ & $1491^{\mathrm{ab}}$ & $1388^{b c}$ & $7266^{\mathrm{ab}}$ & $3297^{\mathrm{a}}$ & $2267^{\mathrm{a}}$ & $3677^{\mathrm{ab}}$ & $9241^{\mathrm{ab}}$ & $4382^{\mathrm{a}}$ & $1958^{\mathrm{ab}}$ & 948 & $7288^{a}$ & $23794^{\mathrm{a}}$ \\
\hline & 100 & $4293^{a}$ & $1542^{\mathrm{ab}}$ & $1576^{\mathrm{ab}}$ & $7412^{\mathrm{ab}}$ & $3502^{\mathrm{a}}$ & $2386^{\mathrm{a}}$ & $3883^{\mathrm{ab}}$ & $9770^{\mathrm{a}}$ & $4446^{a}$ & $2225^{\mathrm{a}}$ & 944 & $7615^{\mathrm{a}}$ & $24797^{a}$ \\
\hline & 125 & $4609^{a}$ & $1653^{\mathrm{a}}$ & $1824^{\mathrm{a}}$ & $8086^{\mathrm{a}}$ & $3461^{\mathrm{a}}$ & $2347^{a}$ & $4030^{\mathrm{a}}$ & $9839^{a}$ & $4094^{a}$ & $2360^{a}$ & 719 & $7172^{\mathrm{a}}$ & $25097^{\mathrm{a}}$ \\
\hline & 150 & $4821^{\mathrm{a}}$ & $1510^{\mathrm{ab}}$ & $1885^{\mathrm{a}}$ & $8216^{\mathrm{a}}$ & $3387^{\mathrm{a}}$ & $2216^{\mathrm{a}}$ & $4003^{\mathrm{a}}$ & $9606^{\mathrm{a}}$ & $3844^{\mathrm{a}}$ & $2631^{\mathrm{a}}$ & 689 & $7164^{\mathrm{a}}$ & $24986^{\mathrm{a}}$ \\
\hline \multirow{3}{*}{\multicolumn{2}{|c|}{$\begin{array}{l}\text { F-arvo } \\
\text { DF } \\
\text { p-arvo }\end{array}$}} & 1,55 & 3,04 & 3,59 & 2,68 & 3,23 & 6,66 & 3,52 & 2,74 & 19,61 & 7,03 & 6,23 & 8,32 & 6,11 \\
\hline & & 20,75 & 20,75 & 20,75 & 20,75 & 20,75 & 20,75 & 20,75 & 20,75 & 20,75 & 20,75 & 20,75 & 20,75 & 20,75 \\
\hline & & $0,0889 \mathrm{o}$ & $0,0003 * * *$ & $<, 0001 * * *$ & $0,0011 * *$ & $<, 0001 * * *$ & $<, 0001 * * *$ & $<, 0001 * * *$ & $0,0009 * * *$ & $<, 0001 * * *$ & $<, 0001 * * *$ & $<, 0001 * * *$ & $<, 0001 * * *$ & $<, 0001 * * *$ \\
\hline
\end{tabular}

$-{ }^{1} 1$. ja 2. sadolle tasonmukainen typpilannoitus. 3. sadolle $50 \mathrm{~kg} \mathrm{~N} / \mathrm{ha}$.

_ ${ }^{\text {a,b,c,d,e }}$ Saman sarakekokonaisuuden käsittelykeskiarvot, joilla ei ole yhteistä kirjainta, eroavat tilastollisesti merkitsevästi 5 \%:n riskitasolla. 
Ensimmäisen satovuoden ensimmäisen niiton sato oli yhtä suuri lannoitusmenetelmästä riippumatta, joten koekentän mahdollisilla poikkeavuuksilla ei ollut vaikutusta (taulukko 1). Myös seuraavina satovuosina ensimmäisen niiton kuiva-ainesadot olivat yhtä suuret edellisen vuoden lannoitusmenetelmästä riippumatta, joten edellisen vuoden sijoitus ensimmäisen niiton jälkeen ei enää vaikuttanut seuraavan vuoden ensimmäisen niiton kuiva-ainesatoon. Sijoitusmenetelmien käyttäminen ilman keskinäistä eroa alensi satovuosien yhteistä kuiva-ainesatoa keskimäärin 6,8 \% pintalannoitukseen verrattuna. Eri sijoitusmenetelmien erot tulivat parhaiten esiin toisen niiton kuiva-ainesadossa, koska sijoitusmenetelmää käytettiin juuri kyseisen sadon lannoittamiseen. Toisesta satovuodesta lähtien lautasvantaan käyttö tuotti paremman, 7,7 \% (2002) ja 9,1 \% (2003), toisen niiton kuiva-ainesadon kuin lietteensijoitusvannas. Kiekkovannas asettuu näiden välille, mutta ei poikennut merkitsevästi kummastakaan. Ensimmäisenä satovuotena sijoitusmenetelmien käyttö aiheutti toisen niiton kuiva-ainesadossa huomattavan 31,7 \%:n tappion pintalannoitukseen verrattuna. Toisena satovuotena lautasvantaan ja lietesijoitusvantaan käyttö aiheutti vastaavasti 14,7 \%:n ja 20,8 \%:n, kolmantena satovuotena vastaavasti 19,4 \%:n ja 26,1 \%:n tappion. Lautasvantaan käytön aiheuttama tappio satovuosien yhteisessä kuiva-ainesadossa oli kuitenkin vain 5,2 \% pintalannoitukseen verrattuna. Tyynelän ja Kapuisen (2001) aikaisemmassa vastaavassa tutkimuksessa, jossa väkilannoite kuitenkin sijoitettiin kummallekin ensimmäiselle sadolle ja kolmatta ei korjattu, vanhalla timoteinurmella vuonna 1998 sijoituslaitteet asettuivat paremmuudessaan samaan järjestykseen, mutta erot eivät olleet merkitseviä. Englanninraiheinälle on tyypillistä, että toisesta satovuodesta lähtien sato painottuu toiseen niittoon, joten se kärsi lannoitteen sijoittamisesta ensimmäisen niiton jälkeen. Sen lannoitteen sijoittaminen jo keväällä toisesta satovuodesta lähtien olisi saattanut tuottaa paremman satovuosien yhteisen kuiva-ainesadon. Sijoituslannoituksella saatavan sadon sulavuus oli parempi kuin pintalannoituksella saatavan, mikä pienentää satotappion merkitystä.

Tulosten valossa (taulukko 2 ja 3 ) nykyisen ympäristötukijärjestelmän tarkennetun lannoituksen typpilannoitusrajat ovat varsin kohdallaan. Timotein satovuosien kuiva-ainesato ei kasvanut merkitsevästi ensimmäisen ja toisen sadon lannoituksen kasvaessa yli $75 \mathrm{~kg} \mathrm{~N} / \mathrm{ha}$ ja muiden heinien yli $100 \mathrm{~kg}$ N/ha. Sen sijaan Tyynelän ja Kapuisen (2001) aikaisemmassa tutkimuksessa vanha timoteinurmi hyötyi toisessa sadossa $125-150 \mathrm{~kg} \mathrm{~N} / \mathrm{ha}$ lannoituksesta. Tämä ero ei liittynyt sijoittamiseen, koska vaikutus oli sama riippumatta siitä, oliko typpitasojen lannoite sijoitettu vai levitetty pinnalle. Ilmeisesti kysymys on maalaji- ja kasvupaikkaerosta, joiden vaikutuksia pitäisi jatkossa selvittää. Tässä tutkimuksessa typpilannoituksen lisäämisestä oli hyötyä ensimmäisenä satovuotena koiranheinän ja Englanninraiheinän, toisena satovuotena vain Englanninraiheinän kolmannen sadon muodostumiselle. Se ei kuitenkaan näkynyt kunkin satovuoden kokonaiskuiva-ainesadossa merkitsevänä vaikutuksena. Tutkimuksen typpilannoitusportaat, $25 \mathrm{~kg} \mathrm{~N} / \mathrm{ha}$, vastaavat esimerkiksi $100 \mathrm{~kg} / \mathrm{ha}$ Tigoteam Oy:n lannoitetta VR250000, jonka hinta oli marraskuussa 2003 156,30 €/t eli 15,63 €/ha per porras (MT 2003). Ohran hinta oli 106,79 €/t (ka 86 \%) (MT 2003). Heinäsäilörehujen ry-arvo on noin 0,92 ry/kg ka ohran 1,14 ry/kg ka. Ohran hinnasta ry-arvon avulla johdettu säilörehun arvo oli 100,21 €/t ka, jolloin yhden typpilannoitusportaan lannoitteen arvo vastasi noin $156,0 \mathrm{~kg} \mathrm{ka} / \mathrm{ha}$ satoeroa. Kokeessa yhden sadon tasolla merkitseviksi osoitettavissa olevat erot olivat 2,7 - 7,2 kertaa, satovuositasolla 3,4-4,1 kertaa ja kaikkien satovuosien tasolla 2,3 kertaa lisälannoitusportaan kustannuksen arvoisia.

\section{Johtopäätökset}

Ruokonata tuotti selvästi suurimman kuiva-ainesadon eikä tarvinnut sadon muodostumiseen normaalia suurempaa typpilannoitusta. Se soveltui satovuosien aikaiseen sijoituslannoitukseen yhtä hyvin kuin perinteiset nurmiheinät. Kun fosforia sisältäviä lannoitteita tai lietelantaa liukoisen fosforin huuhtoutumisen aiheuttamien ympäristöhaittojen välttämiseksi sijoitetaan nurmeen, se tulisi mahdollisuuksien mukaan aloittaa vasta toisena satovuotena ja se tulisi tehdä Englanninraiheinää lukuun ottamatta ensimmäisen niiton jälkeen käyttäen lautasvannasta. Lietelannansijoitusvannas vaurioittaa nurmea tätä enemmän, mutta jos liete sijoitetaan vain kerran vuodessa ensimmäisen niiton jälkeen, ero lautasvantaan käyttöön ei ole merkittävä kokonaiskuiva-ainesadossa. Englanninraiheinälle saattaisi kevätsijoitus olla parempi vaihtoehto toisesta satovuodesta lähtien.

\section{Kirjallisuus}

MT 2003. Maaseudun Tulevaisuus 17.11.2003.

Tyynelä, S. \& Kapuinen, P. 2001. Placement technique as a means of reducing environmental hazards related to application of artificial fertilizer on grasslands. Transactions of of EAU 214: 272-277. 